„Przekłady Literatur Słowiańskich”. T. 11, cz. 1, s. 1-24

ISSN 2353-9763 (wersja elektroniczna)

DOI https://doi.org/10.31261/PLS.2021.11.01.09

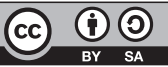

\title{
Wokół słowackich przekładów Lata w Nohant Jarosława Iwaszkiewicza
}

\author{
Around the Slovak Translations \\ of Jarosław Iwaszkiewicz's Lato w Nohant
}

\section{Lucyna Spyrka}

iD https://orcid.org/0000-0001-9124-2678

UNIVERSITY OF SILESIA IN KATOWICE

lucyna.spyrka@us.edu.pl

Data zgłoszenia: 4.02.2021 r. ｜Ｄata akceptacji: 31.05.2021 r.

\begin{abstract}
Jarosław Iwaszkiewicz's drama Lato w Nohant was translated to Slovak twice: first time, before the war, but that translation ultimately did not receive acclaim and fell into oblivion; and then again in the 1970s, during the so-called normalisation of what was at the time Czechoslovakia. In this historical context, this translation would be considered socialist realist. However, the translation of Iwaszkiewicz's text defends itself from such a classification.
\end{abstract}

KEYWORDS | Polish literature in Slovak translations, drama translation, history of translation, translation contexts, Jarosław Iwaszkiewicz 
Twórczość Jarosława Iwaszkiewicza opiera się jednoznacznemu przypisaniu do któregoś z nurtów artystycznych XX wieku. Szerokie rozumienie pojęcia modernizmu pozwala uznać za modernistyczny cały dorobek pisarski tego autora, w tym czternaście napisanych przezeń utworów dramatycznych. Jednym z nich jest Lato $w$ Nohant. Dramat, który opowiada o pobycie Fryderyka Chopina w okresie letnim w latach 40. XIX wieku w Nohant-Vic we Francji w posiadłości pisarki, a zarazem jego kochanki George Sand, po raz pierwszy był publikowany na przełomie roku 1936/1937 w trzech kolejnych numerach "Skamandra"1. Jak dowodzi Dorota Fox, utwór ma cechy dramatu modernistycznego:

\begin{abstract}
Wydaje się, że Lato $w$ Nohant jest dramatem ufundowanym na modernistycznym estetyzmie, zarówno na jego światopoglądowych podstawach, jak i w zakresie wypracowanych na jego gruncie technikach, umożliwiających spiętrzenie piękna, jego zwielokrotnienie, odbicie piękna w innym pięknie, słowem - spotęgowanie przeżycia estetycznego. [...] Mocny związek z estetyzmem zdradza obecna w dramacie tendencja do łączenia kilku różnych dziedzin sztuki (nie tylko w planie treści, ale także w planie wyrażania) i kumulowania (właściwemu sztuce teatru) środków przedstawiających oraz uobecniających nastrój (muzycznych, słownych, obrazowych, aktorskich etc.). Ciążenie w stronę estetyzmu potwierdzają wszelkie -izmy: symbolizm, widoczny między innymi w ujęciu okna, burzy jako ekwiwalentu dramatycznej akcji i fortepianu (można by tu dostrzec odwrócenie figury instrumentu, który w Norwidowskim wierszu sięga bruku), naturalizm uwidaczniający się w konstrukcji akcji, sytuacji scenicznych, dialogu, a także impresjonizm zaznaczony dzięki technice przedstawiania pejzażowego ${ }^{2}$.
\end{abstract}

Iwaszkiewicz połączył w utworze różne formy sztuki: literackie słowo, muzykę ( $\mathrm{w}$ tle wydarzeń w ciągu całego utworu brzmi komponowana właśnie przez Chopina Sonata h-moll i te „narodziny muzyki” stają się najważniejszym wydarzeniem na końcu dramatu) oraz plastycznie potraktowaną przestrzeń (Fox zwraca uwagę, że już sam tytuł ma charakter „malarski”, pejzażowy: Lato $w$ Nohant $^{3}$ ).

1 W każdym numerze czasopisma ukazywał się jeden akt utworu: akt I: „Skamander. Miesięcznik poetycki” 1936, r. 10 (t. 10), z. 77, s. 516-534; akt II: „Skamander. Miesięcznik poetycki” 1937, r. 11 (t. 11), z. 78-80, s. 26-43; akt III: „Skamander. Miesięcznik poetycki" 1937, r. 11 (t. 11), z. 81-83, s. 104-121.

2 D. Fox, 2009: Gra przestrzenia w sztuce Jarosława Iwaszkiewicza "Lato w Nohant” $i w$ jej scenicznych realizacjach. W: V. Sajkiewicz, E. Wąchocka, red.: Przestrzenie we wspótczesnym teatrze i dramacie. Katowice, Wydawnictwo Uniwersytetu Śląskiego, s. $72-73$ [podkreśl. - D.F.].

3 Ibidem, s. 69 i nast. 
W centrum uwagi w utworze znajdują się słynne postaci: George Sand i Chopin, przy czym Iwaszkiewicz wchodzi w polemikę z obowiązującymi stereotypowymi wyobrażeniami na ich temat. Sand, postrzegana jako kobieta wyzwolona, przełamująca obowiązujące konwenanse, wręcz buntowniczka i prowokatorka, a przy tym demokratka - w sztuce Iwaszkiewicza okazuje się zupełnie inna. Usiłuje manipulować otoczeniem, przede wszystkim swoimi dziećmi, którym całkiem konwencjonalnie i niedemokratycznie próbuje narzucić własne, jednak konserwatywne oraz, jak powiedzielibyśmy dziś, nastawione konsumpcjonistycznie koncepcje i wizje ich życia. Nadto jeśli jest w niej coś z buntowniczki, to ma to na celu tylko wsparcie kariery pisarki, zatem jej bunt okazuje się pozorny. Sand jest małostkowa i emocjonalnie powierzchowna: w chwili rozstania z Chopinem ważniejsze od jakichkolwiek emocji okazuje się dla niej wyłudzenie od wyjeżdżającego wieloletniego partnera prezentu w postaci zielonego pudełka na buty. Zakwestionowaniu podlega też miłość Sand do Chopina, o którym mówi, że jest grajkiem, nie docenia jego pracy, wręcz wyraża się o niej z lekceważeniem, a nawet z pogardą, stawiając swoją twórczość literacką nad wszelką twórczością muzyczną, w tym również nad kompozytorstwem swego byłego już kochanka. Chopina Iwaszkiewicz również zdejmuje z piedestału, przedstawiając go jako człowieka skupionego przede wszystkim na sobie i swojej pasji, nie zawsze sympatycznego, niekiedy kapryśnego, który wszystko i wszystkich podporządkowuje własnej pracy kompozytorskiej. Obie postaci prezentuje więc Iwaszkiewicz kontrastowo i z pewną ironią. Ironia zresztą jest obecna w utworze również w odniesieniu do innych kwestii, na przykład do pojęcia polskości, relacji polsko-francuskich, polskiej emigracji, relacji pomiędzy George Sand i jej dziećmi itd. W głównej mierze na ironii właśnie opiera się komizm w utworze. Sam autor określił dramat jako komedię w trzech aktach.

Prapremiera teatralna Lata $w$ Nohant odbyła się 4 grudnia 1936 roku w Teatrze Małym w Warszawie. Inscenizacja okazała się sporym sukcesem. Pochlebnie o samym utworze i jego teatralizacji pisali między innymi Tadeusz Boy-Żeleński i Karol Irzykowski. W „Skamandrze” ukazała się recenzja autorstwa Ireny Krzywickiej, czytamy w niej:

[...] premiera sztuki Iwaszkiewicza Lato $w$ Nohant została przyjęta owacyjnie. Sukces pisarza, który dotąd nie miał szerokiej popularności, ale był wybitnie ceniony przez znawców poezji i prozy, jest zupełny. Przybył Polsce dramaturg o znakomitym wyczuciu sceny, wybitnej kulturze i darze przepajania swojej wizji autentyczną poezją, co jest jednym z najrzadszych talentów ${ }^{4}$.

4 I. Krzywicka, 1937: Przegląd teatralny. „Skamander. Miesięcznik poetycki”, r. 11 (t. 11), z. $78-80$, s. 62 . 
Krytycy zgodnie podkreślali umiejętne podjęcie tematu z biografii Chopina. Irzykowski stwierdził:

[...] nie popaść w pospolite inscenizowanie anegdot z życia sławnych ludzi i z opornego, bo zanadto już przez biografikę ustalonego, materiału zrobić dobrą komedię, na to potrzeba i znawstwa rzeczy, i talentu oczywiście, i szczęścia, aby się to wszystko razem połączyło ${ }^{5}$.

Podobnie wypowiedziała się Krzywicka:

Przedsięwzięcie jego [Iwaszkiewicza - L.S.] na pozór wydawało się karkołomne, pokazywanie na scenie historycznych postaci, zwłaszcza artystów, jest rzeczą bardzo niebezpieczną. I jeszcze w dodatku pokazać półboga — samego Chopina. Dreszcz przechodzi na myśl, czym by to mogło być, gdyby dotknął tego ktoś ciężką łapą. Jakże niewielka przestrzeń może dzielić na scenie figurę geniusza od żałosnego bufona! ${ }^{6}$

Dramat na język słowacki był tłumaczony dwukrotnie. Pierwszy przekład pojawił się w bardzo krótkim czasie od chwili publikacji oryginału, bo już 6 kwietnia 1938 roku odbyła się prapremiera Lata $w$ Nohant na scenie Słowackiego Teatru Narodowego w Bratysławie ${ }^{7}$. O tak szybkim powstaniu słowackiego tłumaczenia i inscenizacji dramatu zadecydowało wiele czynników, nie tylko sukces, jaki oryginał odniósł w kontekście rodzimym. Słowacy interesowali się tym, co działo się w literaturze i kulturze polskiej co najmniej od lat 20. XIX wieku, wśród działaczy narodowych skupionych wokół Ludovíta Štúra zainteresowanie było tak duże, zwłaszcza twórczością Adama Mickiewicza, że czytali oni literaturę polską w oryginale. W tym samym okresie również teatr słowacki chętnie sięgał po sztuki polskich autorów, zwłaszcza po komedie Aleksandra Fredry, a pod koniec stulecia - także po komedie Michała Bałuckiego. Trzeba wszakże pamiętać, że aż do 1920 roku teatr słowacki był teatrem wyłącznie amatorskim, działającym przede wszystkim w środowisku wiejskim lub małomiasteczkowym, co przekładało się na możliwości inscenizacyjne, a tym samym na wybór repertuaru. Dopiero w 1920 roku powstała pierwsza i na długo jedyna słowacka scena profesjonalna - Słowacki Teatr Narodowy w Bratysławie. W początkowym

5 K. Irzykowski, 1966/1967: J. Iwaszkiewicz - Lato w Nohant. W: Przewodnik teatralny. Jarosław Iwaszkiewicz: Lato w Nohant. Białystok, Państwowy Teatr Dramatyczny im. Al. Węgierki w Białymstoku, s. 6. Dostępne w Internecie: e-teatr.pl/files/progra my/51299/lato_w_nohant_teatr_wegierki_bialystok_1967.pdf [dostęp: 20.09.2020].

6 I. Krzywicka, 1937: Przeglad teatralny...

7 eTHEATRE.SK, Divadelný ústav Bratislava, Inscenácie, https://etheatre.sk/du_vade mecum/permalinkdu?xid $=298 \mathrm{~b} 3 \mathrm{f} 30 \mathrm{~d} 65 \mathrm{f} 4225 \mathrm{~b} 032 \mathrm{~d} 57 \mathrm{dc5} 5 \mathrm{cc} 2 \mathrm{e} \& \mathrm{modeView}=\mathrm{LIST}$ [dostęp: 17.11.2020]. 
okresie swej działalności większość inscenizacji prezentował on jednak w języku czeskim z braku odpowiedniego słowackiego repertuaru (wobec słabości sceny profesjonalnej słowackie życie teatralne skupiało się nadal w kręgu amatorskim, co przekładało się też na rodzimą twórczość dramatopisarską, w dalszym ciągu nastawioną przede wszystkim na teatry amatorskie i gust ich publiczności) i większej grupy słowackich aktorów (początkowo było ich jedynie pięcioro). Co prawda, w ciągu pierwszej dekady istnienia profesjonalnego Słowackiego Teatru Narodowego niedostatki kadrowe udało się wyrównać na tyle, że w 1932 roku doszło do rozdzielenia zespołu teatru na dwie osobne sceny: czeską i słowacką, jednak problem doboru repertuaru dla sceny słowackiej nadal pozostał aktualny. Słowaccy pisarze od początku istnienia narodowego teatru profesjonalnego starali się podejmować z nim współpracę, jednak ich utwory często ani pod względem literackim, ani teatralnym nie osiągały poziomu artystycznego, który byłby w stanie konkurować z dramatami czeskimi. Braków repertuaru rodzimego scena słowacka nie mogła nadrobić tłumaczeniami dramatu obcego, gdyż i pod tym względem scena czeska była w sytuacji korzystniejszej. Dramat obcy był dostępny głównie w przekładach na język czeski, przekładów słowackich właściwie nie było, intensyfikacja aktywności translatorskiej w kręgu słowackim nastąpiła dopiero w latach 30. Nadto funkcjonowanie obok siebie sceny czeskiej i słowackiej niosło ze sobą niebezpieczeństwo dublowania się repertuaru, wysiłki kierownictwa teatru skupiały się więc na zapobieganiu takim sytuacjom. Ten splot okoliczności zmuszał kierownictwo sceny słowackiej do poszukiwań repertuarowych, zwróciło się więc w stronę tych literatur, z których tłumaczenie wydawało mu się najłatwiejsze i do których poziomu twórczości dramatopisarskiej miało największe zaufanie. Tym kręgiem było dramatopisarstwo słowiańskie, w tym polskie ${ }^{8}$. Dzięki temu na słowackiej scenie bratysławskiego teatru w latach 30. XX wieku pojawily się utwory Karola Rostworowskiego Niespodzianka (Prekvapenie, 1930, tłum. K. Sidor), Włodzimierza Perzyńskiego Dziękuję za służbe (Ďakujem za službu, 1932, tłum. M. Zatko), Brunona Winawera R.H. inżynier (R.H. inžinier, 1933, tłum. M. Zat'ko), Stefana Kiedrzyńskiego Szczęście od jutra (Štastie od zajtra, 1934; pod tytułem Babie leto, 1939, tłum. M. Stano), Antoniego Słonimskiego Rodzina (Čistá rasa, 1934, tłum. M. Stano), Jerzego Szaniawskiego Adwokat i róże (Advokát a ruže, 1937, tłum. M. Stano), Anatola Sterna Szkoła geniuszów (Škola géniov, 1938, tłum. M. Babiaková) ${ }^{9}$ oraz interesujący nas dramat

8 L. Čavojský, 1999: Slovenská činohra SND 1932-1938 v zrkadle dramaturgie. W: M. Mistrík a kolektív: Slovenské divadlo v 20. storočí. Bratislava, Veda - vydavatelstvo SAV, s. 82-91, 101-102.

9 R. Mrlian, red., 1990: Encyklopédia dramatických umení Slovenska 2: $M-Z ̌$. Bratislava, Veda, s. 205. W latach 20. w repertuarze teatru znalazły się tylko dwa przetłumaczone na język słowacki dramaty polskie: Stefana Żeromskiego Uciekła mi przepióreczka 
Jarosława Iwaszkiewicza Lato $w$ Nohant ${ }^{10}$. Sam Iwaszkiewicz w 1938 roku nie był zupełnie nieznany w ówczesnej Czechosłowacji: rok wcześniej wyszedł w Czechach przekład jego Panien $z$ Wilka ${ }^{11}$.

Autorem słowackiego tłumaczenia Lata w Nohant był Andrej Žarnov, mający już wówczas w dorobku przekłady polskiej poezji od Mickiewicza po Tuwima, zebrane w antologii U pol'ských básnikov (1936). Publikacja ta odbiła się głośnym echem na Słowacji, wzbudzając duże zainteresowanie tamtejszej krytyki literackiej. Pracę Žarnova dostrzegła również strona polska, nagradzając tłumacza Srebrnym Wawrzynem Akademickim Polskiej Akademii Literatury ${ }^{12}$.

Po stronie słowackiej dramat Iwaszkiewicza nie spotkał się z dobrym przyjęciem. Jak pisze Ladislav Čavojský:

Jednoznačne u všetkých kritikov prepadla aj hra Jaroslava Iwaszkiewicza Leto $v$ Nohante (1938) [...]. Autor nezobrazil dvoch géniov vo výnimočných situáciách, ale výnimočne ich chcel predstavit’ v každodennom živote, 'no v malých veciach ich urobil skutočne malichernými a vo vel'kých im vložil do úst len patetické prázdne slová $^{13}$.

Nie można wykluczyć, że do tak druzgocącej oceny przyczyniło się samo ujęcie tematu przez Iwaszkiewicza. Natomiast pod względem poetyki dla sło-

(Uletla mi prepelička, 1925, tłum. F. Hrušovský), Henryka Zbierzchowskiego Małżeństwo Loli (Lolino manželstvo, 1928, tłum. A. Krupa). W języku czeskim wystawiono Stanisława Przybyszewskiego Dla szczęścia (1920), Stefana Kiedrzyńskiego Zabawę w miłość (1924) oraz Gabrieli Zapolskiej Moralność pani Dulskiej (1928). Zob. ibidem.

$10 \mathrm{Na}$ fakt, że utwór Iwaszkiewicza tak szybko od polskiej premiery doczekał się premiery słowackiej, wpływ miał też zapewne ówczesny stan stosunków polityczno-kulturalnych polsko-czechosłowackich i polsko-słowackich. W latach 20. na wzajemnych relacjach poważnie zaciążyły spory o Śląsk Cieszyński, Jaworzynę i Spisz, ale narastające na Słowacji od połowy dekady nastroje antyczeskie i zmiany w polskiej polityce zagranicznej lat 30., związane z osobą Józefa Becka i koncepcją Międzymorza („Trzeciej Europy"), spowodowały wzrost zainteresowania sprawami słowackimi w Polsce. Doprowadziło to do wyraźnego politycznego zbliżenia obu stron, a wraz z nim do intensyfikacji kontaktów kulturalnych. Por. J. Russocka, 1972: Literatura słowacka w polskich czasopismach okresu międzywojnia. W: M. Bakoš, red.: Vztahy slovenskej a pol'skej literatúry od klasicizmu po súčasnost'. Bratislava, Vyd. SAV, s. 193, 199; J. Hvišč, 2000: Národné povedomie v medziliterárnych súvislostiach. W: J. Hvišč, red.: Historické a kultúrne zdroje slovensko-polských vztahov. Bratislava, Vyd. Lufema, s. 83.

11 J. Iwaszkiewicz, 1937: Slečny ze statku. V. Dresler, prel. Praha, Vyd. L. Mazáč.

12 O. Kovačičová, M. Kusá, zost., 2017: Slovník slovenských prekladatelov umeleckej literatúry. 20. storočie. $L-Z \check{Z}$. Bratislava, Veda - vydavatelstvo SAV, s. 360-362.

13 L. Čavojský, 1999: Slovenská činohra SND 1932-1938 v zrkadle dramaturgie. W: Slovenské divadlo v 20. storočí. Bratislava, Vyd. Veda, s. 102. Badacz cytuje recenzję jp.: Nepodarené predstavenie slovenskej činohry. „Slovenské Zvesti”, roč. 3, 10.04.1938, č. 71, s. 8 . 
wackiego odbiorcy utwór ten nie stanowił całkowitej nowości. Jak wskazują sami Słowacy, w tym czasie w ich historii dramatu trwał okres przejścia od realizmu do modernizmu i poetyk awangardowych, a tradycyjnie popularna wśród Słowaków komedia operowała satyrą i ironią ${ }^{14}$. Pod względem tematycznym ówczesna słowacka twórczość dramatyczna nie ograniczała się wyłącznie do problemów wsi, ale wśród ukazywanych przestrzeni był tu także salon, tyle że nie wielkopański, a mieszczański. Jeśli salon George Sand w Lecie w Nohant mógł się wydawać słowackiemu odbiorcy obcy, to dlatego że salon ów znajdował się na styku kultury francuskiej i polskiej, podczas gdy tradycyjne związki kultury słowackiej z francuską były zdecydowanie słabsze, mimo dostrzegalnego ich ożywienia właśnie w okresie międzywojennym.

Warto byłoby też sprawdzić, czy do negatywnej oceny dramatu Iwaszkiewicza przez słowackich recenzentów nie przyczynił się przekład albo czy nie była ona efektem inscenizacji utworu. W odniesieniu do dramatu trzeba bowiem pamiętać, że inscenizacja stanowi formę jego interpretacji, a wersja teatralna nawet w zakresie słowa scenicznego nie musi być w pełni zgodna z wersją tekstu pisanego. Zgodnie z informacją zamieszczoną na stronie archiwum bratysławskiego Instytutu Teatralnego losy tej inscenizacji skończyły się na jednorazowym odegraniu spektaklu ${ }^{15}$. Prawdopodobnie możliwa byłaby częściowa jej rekonstrukcja, gdyż w tym samym archiwum zachował się egzemplarz inspicjencki, do którego jednak na razie nie udało się dotrzeć. Nie udało się też dotrzeć do samego tekstu przekładu, który jest dostępny wyłącznie w Słowackiej Bibliotece Narodowej w Martinie. Przy egzemplarzu w katalogu bibliotecznym widnieje rok 1960 jako rok opublikowania przekładu, jednak brak wydawcy i miejsca wydania. Można zatem podejrzewać, że nie chodzi o oficjalną publikację, lecz o formę tzw. samizdatu, co byłoby uzasadnione, jeśli wziąć pod uwagę powojenne losy Andreja Žarnova (właśc. František Šubík) — w życiu pozaliterackim lekarza patomorfologa, w Państwie Słowackim profesora bratysławskiego uniwersytetu, który jako sygnatariusz protokołów katyńskich z 1943 roku był po wojnie represjonowany przez władze komunistycznej Czechosłowacji, a jego dorobek literacki, zarówno własna twórczość poetycka, jak i twórczość przekładowa, był

14 Por. V. Štefko, 2011: Od realizmu k moderne 1890-1938. W: V. Štefko a kolektív: Dejiny slovenskej drámy 20. storočia. Bratislava, Divadelný ústav, s. 15-43; D. Kročanová, 2019: Impulzy a inovácie v slovenskej dráme medzi rokmi 1920-1948. W: D. Kročanová: Antológia slovenskej drámy 1920-1948. Bratislava, Univerzita Komenského, s. $350-359$.

$15 \mathrm{~W}$ archiwalnych danych Instytutu Teatralnego w Bratysławie przy liczbie repryz słowackiej inscenizacji Leta $w$ Nohante widnieje zero. Zob. eTHEATRE.SK, Divadelný ústav Bratislava, Inscenácie, https://etheatre.sk/du_vademecum/permalinkdu?xid= 2 98b3f 30d65f4225b032d57dc5c 5cc2e\&modeView=LIST [dostęp: 17.11.2020]. 
objęty ścisłym zakazem publikowania. Dotarcie do tych prac obecnie uniemożliwia jednak nie sytuacja polityczna, lecz pandemia koronawirusa, z powodu której nie można przeprowadzić niezbędnej kwerendy. Analiza tekstu przekładu Lata w Nohant, którego dokonał Žarnov, zostaje zatem zadaniem na przyszłość.

Po raz drugi dramat Iwaszkiewicza został opublikowany w słowackim przekładzie w roku 1975. Tym razem autorem tłumaczenia był Ladislav Jánsky, tłumacz z dużym doświadczeniem, przede wszystkim w zakresie przekładu dramatu i prozy, który aktywność translatorską rozpoczął jeszcze w okresie przedwojennym, tłumacząc współczesne utwory czeskie i węgierskie dla słowackiego radia. Jako tłumacz literatury polskiej Jánsky zaprezentował się w latach 60. XX wieku ${ }^{16}$. Drugi słowacki przekład utworu Iwaszkiewicza powstał już w zmienionych w stosunku do przekładu pierwszego okolicznościach historyczno-politycznych i na innym etapie rozwoju słowackiego dramatu i teatru. Na terenie Słowacji działała wówczas sieć profesjonalnych teatrów tzw. repertuarowych, które w doborze repertuaru miały do dyspozycji nie tylko niemały już rodzimy dorobek dramatopisarski, lecz także całkiem szeroki zestaw przetłumaczonych dramatów obcych. Jak stwierdza badaczka dziejów przekładu artystycznego w kulturze słowackiej Katarína Bednárová, po roku 1938 właśnie w sferze przekładu dramatu nastąpiły największe zmiany: zwiększyła się aktywność tłumaczy sięgających zarówno po tytuły współczesne, jak i po klasykę światową i tym samym nadrabiających niedostatki słowackie w tym zakresie ${ }^{17}$. Działające od 1949 roku stowarzyszenie DILIA (od 1949 roku DILIZA, od 1969 - LITA), skupiające pisarzy i tłumaczy zajmujących się głównie twórczością dramatyczną, opublikowało setki powielaczowych wydań tłumaczeń dramatów na potrzeby teatrów profesjonalnych i amatorskich. W ślad za tym:

16 Ladislav Jánsky (właśc. L. Kiss, 1914-1989) — studiował słowacystykę i polonistykę w Bratysławie i w Warszawie (1934-1938). Był nauczycielem szkoły średniej, w latach Państwa Słowackiego na krótko został urzędnikiem w resorcie kultury rządzącej w kraju partii Hlinkovej Slovenskej Ludovej Strany (1944-1945). Po wojnie pracował jako redaktor w czasopismach, m.in. w piśmie „Praca” oraz w wydawnictwie LITA. Publikował przekłady, recenzje, próbował sił we własnej twórczości dramatycznej. Tłumaczył głównie prozę oraz dramat czeski i węgierski, rzadziej polski. Z polskich utworów przełożył Zofii Bystrzyckiej Czy to jest miłość? (To je láska?, 1965), Tadeusza Łopalewskiego Sklejony garnek (Zglejený hrnček, 1970), Agnieszki Osieckiej Apetyt na czereśnie (Chut na čerešne, 1973), Gabrieli Zapolskiej Skiz (Najvyšši tromf, 1974). O. Kovačičová, M. Kusá, zost., 2015: Slovník slovenských prekladatelov umeleckej literatúry. 20. storočie. A-K. Bratislava, Veda - vydavatel'stvo SAV, s. 298-299.

17 K. Bednárová, 2015: Kontexty slovenského umeleckého prekladu 20. storočia. W: O. Kovačičová, M. Kusá, zost.: Slovník slovenských prekladatelov umeleckej literatúry. 20. storočie. A-K..., s. 51. 
Preklad dramatických textov sa postupne dostal do vydavatelstiev, ktoré začali publikovat výbery zo svetových dramatikov v kvalitných knižných prekladoch, napr. v edíciách Svetoví klasici, Divadelné hry či Edícia divadelných hier vo vydavatel'stve Tatran, ktoré malo aj prvenstvo v etablovaní vydávania nových dramatických žánrov, ako literárne scenáre k filmom. Divadelné texty vychádzali ako antológie — napr. Moderná svetová dráma (1964), Moderná americká dráma (1965), Moderná nemecká dráma (1967), Francúzske romantické divadlo (1967), Moderná talianska dráma (1968), Moderná anglická dráma (1970), ale aj ako autorské a tematické výbery ${ }^{18}$.

Nowy przekład Lata w Nohant wszedł w skład antologii Moderná pol’ká dráma, wydanej w 1975 roku. Zbiór ten przygotował Ján Sedlák — znakomity tłumacz literatury francuskiej i polskiej ${ }^{19}$. Tom opatrzył posłowiem, przybliżającym słowackiemu odbiorcy polską twórczość dramatyczną od początku XX wieku aż do lat 70., poświęcając szczególną uwagę kilku autorom i ich utworom. Wyróżnił w ten sposób Wesele Wyspiańskiego, Lato w Nohant Iwaszkiewicza, Dwa teatry Szaniawskiego, twórczość Witkacego, Kruczkowskiego, Mrożka, Różewicza oraz Na szkle malowane Brylla. W antologii natomiast oprócz interesującego nas dramatu Iwaszkiewicza znalazły się przekłady Dwóch teatrów Szaniawskiego (tłum. J. Sedlák), Śmierci gubernatora Kruczkowskiego (tłum. J. Sedlák) oraz Na szkle malowanego Brylla (tłum. E. Štercová). Prezentacja czterech utworów czterech autorów obowiązywała jako zasada w całej serii wydawniczej, w której ukazał się tom polskich dramatów. Jednak wybór autorów i utworów w polskim tomie sprawił, że dramat Iwaszkiewicza znalazł się

18 Ibidem.

19 Ján Sedlák (1914-2007) - aktywność translatorską rozpoczął jeszcze w latach 40., w ówczesnym Państwie Słowackim, kiedy to w okresie 1941-1944 pracował jako kierownik literacki Słowackiego Teatru Narodowego i odpowiadał za jego repertuar. W tym czasie skupiał się wyłącznie na literaturze francuskiej. Przekładom literatury polskiej zaczął się poświęcać od końca lat 40 . W jego dorobku translatorskim znaleźć można m.in. takie pozycje, jak: powieści Balzaca, Verne’a, Andrzejewskiego, Sienkiewicza, Gojawiczyńskiej, Żeromskiego, Korczaka, Lema, Żukrowskiego oraz liczne utwory dramatyczne, m.in. Sartre’a, Fredry, Zapolskiej, Perzyńskiego, Szaniawskiego, Kruczkowskiego, Mrożka czy Różewicza. Był też tłumaczem prozy Jarosława Iwaszkiewicza (Panny z Wilka - Slečny $z$ Vlčian, 1963; Ikar - Ikar, 1977; Nowa miłość, Brzezina, Kongres we Florencji - we wspólnym tomie pt. Nová láska, 1989), tłumaczył również jego dramaty, które wydał w zbiorze Milenci z Marony, 1969. Zarówno z Iwaszkiewiczem, jak i z Kruczkowskim i Żukrowskim Sedlák utrzymywał osobiste kontakty, co pomagało mu nie tylko w pracy translatorskiej, lecz także wzbogacało jego wiedzę na temat literatury polskiej. O. Kovačičová, M. Kusá, zost., 2017: Slovník slovenských prekladatelov umeleckej literatúry. 20. storočie. $L-Z ̌$..., s. $211-214$. 
w antologii w dość zaskakującym towarzystwie, a całość zestawienia z polskiej perspektywy sprawia wrażenie nieco przypadkowego.

Tom ukazał się w okresie, gdy w Czechosłowacji obowiązywał wprowadzony po inwazji wojsk Układu Warszawskiego w sierpniu 1968 roku kurs polityki państwa zwany normalizacją (czes. normalizace, słowac. normalizacia), nastawiony na likwidację osiągnięć Praskiej Wiosny. Dla rozwoju literatury i życia literackiego oznaczało to - mówiąc w uproszczeniu - powrót do warunków z lat 50. XX wieku, a przede wszystkim wzmocnienie ingerencji cenzury. W sferze ideologicznej władze wymagały od literatury zaangażowania w „umocnienie zdobyczy socjalizmu”, w sferze poetyki preferowany był realizm, źle widziana była groteska, niedopuszczalny był absurd. Twórczość, zarówno pisarzy rodzimych, jak i zagranicznych, która nie odpowiadała tym kryteriom, nie mogła być publikowana (w przypadku dramatu - wystawiana w teatrze). Bednárová pisze:

Roky 1971-1980 sú rokmi normalizačnými, v ktorých sa 'upratuje' — nechcené preklady sa odkladajú do skladov knižníc, nechcení prekladatelia do skladov výrobných podnikov. Vo vydavatel'stvách a zväzoch sa preveruje a selektuje, kto smie a kto nesmie prekladat. Dôsledne sa vyberá a schvaluje, čo sa smie prekladat $^{20}$.

Wtóruje jej Jozef Hvišč, opisując ówczesne kontakty polsko-słowackie w sferze literatury:

Vydávanie kníh (aj prekladových) podliehalo prísnej cenzúre, vztahy sa zredukovali na oficiálne styky, výmena literárnych diel, informácie o autoroch a kultúrnych podujatiach boli tendenčne redukované. Politickí činitelia kontrolovali aj časopisecké články, aby sa v nich nevyskytol ani naznak zakázaných polských mien alebo diel. Dôveryhodné osoby vydavatel'stiev a redakcii mali zoznamy pol'ských autorov, ktorí boli pre nás tabu. Podobne boli sledovaní publicisti, kritici a prekladatelia pol'skej literatúry ${ }^{21}$.

Owa „normalizacja” rzutowała nie tylko na wybór utworów, które mogły być udostępnione w przekładzie słowackiemu (i czeskiemu) odbiorcy, lecz także na wybór osoby tłumacza. W takich warunkach nie było możliwe włączenie do antologii istniejącego przekładu Lata w Nohant autorstwa Žarnova, dlatego Sedlák zaprosił do współpracy Jánskiego.

20 K. Bednárová, 2015: Kontexty slovenského umeleckého prekladu 20. storočia..., s. 33.

21 J. Hvišč, 1997: Nová bilancia: slovensko-pol'ské literárne vzt’ahy po roku 1945. W: J. Hvišč, red.: Slovensko-polské jazykové a literárne vzt’ahy. Bratislava, Vyd. T.R.I. Médium, s. 81. 
„Normalizacja” i związana z nią ideologizacja odzwierciedlały się też w sposobie tłumaczenia, choć w latach 70. zjawisko to, jak się wydaje, nie przybierało już aż tak drastycznej formy, jak miało to miejsce w latach 50. minionego stulecia $^{22}$. Wiązało się to ze swoistym tradycjonalizmem, obecnym w słowackiej praktyce translatorskiej już w okresie przedwojennym ${ }^{23}$, a polegającym na nastawieniu na maksymalne poszanowanie oryginału, realizujące się w przekładzie filologicznym, skupiającym się wyłącznie na zachowaniu elementów i cech oryginału ${ }^{24}$. O ile takie podejście do przekładu dominowało w okresie poprzednim, o tyle - jak pisze Anna Valcerová - „[...] nawet postulowana w latach 70. i 80., w dobie tzw. normalizacji, tradycyjność nie zatrzymała trendu przekładów aktualizujących" ${ }^{25}$. Mimo to sytuacja, w jakiej znalazła się literatura przekładowa na Słowacji w latach 70., typowa jest dla „przekładu socrealistycznego", tak jak charakteryzuje go Tamara Brzostowska-Tereszkiewicz. Rolę decydującą odgrywa w nim polityczno-państwowy patronat i dominuje w nim bądź egzotyzacja i liczne periteksty, po to, by maksymalnie zachować przekładowy status tekstu i jego obcość, bądź - na przeciwnym biegunie - skrajna domestykacja w zgodzie z obowiązującymi w kręgu docelowym wymogami ideologicznymi i artystycznymi wraz z cenzurą tekstu źródłowego ${ }^{26}$. W odniesieniu do antologii Sedláka „normalizacja” przejawiała się nie tylko w doborze utworów i ich tłumaczy, lecz także w swoistej manipulacji w odniesieniu do samych oryginałów. Otóż z informacji zawartej w stopce redakcyjnej publikacji odbiorca może się dowiedzieć, na podstawie jakich oryginałów powstały tłumaczenia. Okazuje się, że wszystkie, nawet oba starsze utwory w antologii: Dwa teatry Szaniawskiego, którego pierwsze wydanie w oryginale ukazało się

22 Bednárová opisuje polemikę, jaka toczyła się wówczas na temat słowackiego przekładu powieści Michaiła Szołochowa Cichy Don, w którym na podstawie obranego przez tłumaczkę Zorę Jesenską naturalizującego sposobu tłumaczenia oskarżono ją o niejasne, budzące wątpliwości stanowisko polityczno-ideologiczne, a w języku przekładu dopatrzono się przejawów burżuazyjnego nacjonalizmu, co w tamtym czasie równało się z publicznym potępieniem. Por. K. Bednárová, 2015: Kontexty slovenského umeleckého prekladu 20. storočia..., s. 54.

23 B. Hochel, 1985: Koncepcia prekladu včera, dnes a zajtra. W: J. Vilikovský, zost.: Preklad včera a dnes. Bratislava, Vyd. Slovenský Spisovatel', s. 229-231. Zob. także P. Zajac, 1985: Tvorivost prekladu. W: J. Vilikovský, zost.: Preklad včera a dnes..., s. 272-273.

24 Hochel wskazuje na tzw. ponechávajúci princíp (zasadę pozostawienia), dla której opozycją jest nahradzujúci princíp (zasada zastąpienia). B. Hochel, 1985: Koncepcia prekladu včera, dnes a zajtra..., s. 229.

25 A. Valcerová, 2016: Przekład poezji w Słowacji po roku 1945. M. Buczek, tłum. „Przekłady Literatur Słowiańskich", t. 7, cz. 1, s. 106.

26 T. Brzostowska-Tereszkiewicz, 2015: Przekład modernistyczny (modele i opozycje). W: W. Bolecki, W. Soliński, M. Gorczyński, red.: Współczesne dyskursy konfliktu. Literatura - język - kultura. Warszawa, IBL PAN, s. 88. 
w 1946 roku, oraz Lato $w$ Nohant, opublikowane — jak już wiemy — po raz pierwszy w oryginale jeszcze przed wojną, powstały na podstawie wydań oryginałów z okresu PRL. Bazowały zatem na publikacjach, które z pewnością zostały zaakceptowane przez komunistyczne władze Polski, co dla ówczesnej strony czechosłowackiej mogło stanowić gwarancję ich polityczno-ideologicznej poprawności. Przed porównaniem przekładu utworu z oryginałem warto więc sprawdzić, na ile wydanie oryginału z 1949 roku różni się od pierwszego przedwojennego wydania.

Różnice są nieznaczne. W edycji z 1949 roku nastąpiły w stosunku do publikacji dramatu w „Skamandrze” pewne przesunięcia, dostosowujące utwór do nowych, powojennych realiów. W wydaniu oryginału z 1949 roku znalazło się kilka drobnych zmian w stosunku do wersji z roku 1937, które mogą wskazywać na „światopoglądowe dostosowanie”, choć trudno powiedzieć, czy są efektem działań samego autora, czy wydawcy, czy może cenzora. Zmiany te obejmują przede wszystkim sferę religijną, której elementy, nieliczne w pierwszym polskim wydaniu utworu, znikają w wydaniu z roku 1949. I tak w akcie I brak repliki Augustyny, która gwałtownie reaguje na policzek, jaki Maurycy wymierza Rousseau:

Augustyna: Na Boga, Maurycy, co ty robisz? (I, s. 14) ${ }^{27}$

W akcie III usunięta została wymiana zdań na temat religii w scenie burzliwej rozmowy pomiędzy George Sand a Chopinem. Pisarka krytykuje w niej polski charakter kompozytora:

George Sand: Ta wasza zabobonna ciemna wiara uczyniła $\mathrm{z}$ was ciemnych i niedostępnych mistyków. Ten wasz przeklęty katolicyzm.

Chopin: A czy pani jest ewangeliczką? (III, s. 108)

Ideologicznie motywowana była też zapewne zmiana w replice Chopina, gdy w III akcie dramatu spiera się z George Sand. Pisarka przyznaje, że nie podoba jej się, iż Chopin w ciągu jednego wieczoru odwiedza trzy, a nawet cztery salony.

George Sand: [...] Myślałam, że będziesz grał dla ludu.

Chopin w wydaniu przedwojennym odpowiada:

Chopin: Wolałem grać dla narodu. (III, s. 107)

Natomiast w wydaniu z 1949 roku odpowiedź brzmi:

27 Cytaty z pierwszego wydania dramatu na łamach „Skamandra” oznaczam, podając w nawiasie cyframi rzymskimi akt dramatu, a cyframi arabskimi - numer strony czasopisma. 
Chopin: Na razie musiałem grać dla narodu. (s. 67) ${ }^{28}$

Ta z pozoru tylko drobna zmiana czasownika w istotny sposób modyfikuje jednak sens wypowiedzi kompozytora i odmiennie zarysowuje jego stosunek do sytuacji, w jakiej się znalazł. Dostosowanie ideologiczne polega tu na tym, że w ideologii komunistycznej lud stał ponad narodem, zatem granie dla ludu było ważniejsze od grania dla narodu.

Za dostosowanie do masowego odbiorcy uznać można rezygnację w wydaniu powojennym z repliki George Sand w języku francuskim.

Wodziński: O! Pani tak wcześnie.

George Sand: (ukazując strój swój i Wodzińskiego) Les beaux esprits se rencontrent. (I, s. 517)

W edycji z roku 1949 tej kwestii już nie ma, co można z jednej strony wytłumaczyć uwzględnieniem przez autora wymagań inscenizacyjnych (po co aktorowi utrudniać realizację roli, każąc mu mówić ze sceny w obcym języku?). Z drugiej - jest to być może reakcja autora na inną po wojnie sytuację społeczną, w której znajomość języka francuskiego nie była już tak powszechna jak przed wojną, nie tylko wśród aktorów, lecz przede wszystkim wśród publiczności teatralnej, której profil społeczny w 1949 roku z pewnością był różny od tego z roku 1937.

Z tego samego powodu pewnym modyfikacjom podlega też sposób przedstawienia Chopina. W przekładzie z 1949 roku opuszczono zdanie w replice Sand, w którym w drastyczny sposób opowiada ona o kompozytorze zmagającym się $\mathrm{z}$ atakiem choroby podczas podróży na Majorkę:

George Sand: [...] Przyszły potem różne inne rzeczy, podróż na Majorkę, gdzie histeryzował i umierał naprawdę, gdzie był prawie trupem. Zimny, spocony, przeraźliwie chudy, leżał w moim łóżku. Och, to okropne, Rozjerko! [...]. (I, s. 529)

W wydaniu z 1949 roku zaznaczonego zdania brakuje, co można chyba wytłumaczyć tym, że w tamtym czasie u ludzi, którzy przeżyli II wojnę światową, taki obraz mógł wywoływać traumatyczne skojarzenia.

Owe nieznaczne modyfikacje w tekście oryginału nie miały wpływu na zasadnicze sensy i znaczenie utworu. Natomiast taki zmodyfikowany oryginał jako podstawa drugiego słowackiego przekładu Lata $w$ Nohant w dużej mierze

28 Cytaty z powojennego wydania dramatu przytaczam za: J. Iwaszkiewicz, 1949: Lato $w$ Nohant. Warszawa, Czytelnik. W nawiasie podano numery stron, z których zaczerpnięto cytaty. 
uwalniał tłumacza od obowiązku aktualizacji w zakresie ideologicznego dostosowania tekstu do wymogów patrona po stronie docelowej, choć w niektórych fragmentach i tak ewidentnie się bez niej nie obeszło. Przede wszystkim poddano tekst dalszej laicyzacji, eliminując pozostawione w oryginale przez polskiego wydawcę motywy i wzmianki religijne. Oto w jednej ze scen aktu I postaci dramatu: George Sand, Maurycy, Clésinger i Rousseau spierają się o to, która jest godzina. Clésinger oznajmia: „Mam wrażenie, że właśnie uderzyła pierwsza na kościele” (s. 32). W wydaniu słowackim replika ta pojawia się w wersji: „Zdá sa mi, že na vežových hodinách práve odbila jedna” (s. 30 ${ }^{29}$. W innym miejscu Chopin ma za złe George Sand jej zbytnią poufałość z Rozjerką:

Chopin: A ta twoja Rozjerka, łodyga stara... To ona wszystkie te plotki przed najwyższy ołtarz nosi. (s. 65)

Użyte tu przez kompozytora określenie „najwyższy ołtarz” ma charakter ironiczny, w ten sposób bowiem Chopin nazywa panią domu, czyli samą Sand. W wersji słowackiej czytamy:

Chopin: A ta tvoja Rózka, morka stará... Ved’ to ona všetky tie klebety roznáša ako na jarmoku. (s. 55)

Motywowane ideologicznie zeświecczenie przestrzeni (słowac. jarmok to pol. targ) sprawiło, że owej ironii zabrakło, a w przekładzie obiektem drwiny ze strony Chopina pozostaje jedynie przyjaciółka pani domu.

Jako ideologiczną manipulację, służącą w 1949 roku napiętnowaniu wszystkiego, co wiązało się ze „zgniłym kapitalizmem” na Zachodzie, należy też potraktować drobną zmianę w replice George Sand, która w I akcie skarży się Rozjerce, że Chopin zrobił jej awanturę. W przedwojennym pierwodruku czytamy:

George Sand: Awanturę - oczywiście, taką bez słów, jak to on potrafi, z tym parszywym arystokratycznym chłodem. (s. 21)

W wydaniu słowackim „parszywy arystokratyczny chłód” zmienia się w „paryski arystokratyczny chłód”:

Sandová: Výstup — prirodzenie, taký bez slov, ako to on vie, s tým parížskym aristokratickým chladom. (s. 21)

Poza tymi fragmentami poddanymi ideologicznej aktualizacji Jánsky zaproponował przekład maksymalnie zbliżony do oryginału. W przypadku pary

29 Cytaty słowackiego przekładu dramatu pochodzą z wydania: J. Iwaszkiewicz, 1975: Leto v Nohante. W: Moderná polská dráma. J. Sedlák, vyb. Bratislava, Tatran, s. 7-73. $\mathrm{W}$ nawiasie podano numery stron, $\mathrm{z}$ których zaczerpnięto cytaty. 
języków polski - słowacki ze względu na ich pokrewieństwo taki sposób tłumaczenia bywa opcją w pełni uzasadnioną i często przynoszącą dobre efekty. Natomiast konsekwentne przestrzeganie zasady maksymalnego zachowania cech czy elementów oryginału skutkuje maksymalną egzotyzacją i obcością, co w danych okolicznościach historycznych może świadczyć o tym, że przekład wpisuje się w model socrealistyczny ${ }^{30}$.

Najjaskrawszym przejawem dosłowności w powojennym słowackim tłumaczeniu dramatu Iwaszkiewicza jest pozostawienie w niezmienionym brzmieniu przypisu informującego o tym, że fragment utworu był opuszczany we wszystkich dotychczasowych inscenizacjach (w oryginale s. 82-84, w przekładzie s. 69-70). Brak przy tym wyjaśnienia, że dotyczy to wyłącznie polskich losów teatralnych utworu, gdyż na Słowacji był on inscenizowany wyłącznie raz przed wojną. O dążeniu do egzotyzacji świadczyć może również zmiana form imion i nazwisk niektórych postaci sztuki. Oto imię Maurycy z polskiego oryginału podlega romanizacji i w wersji słowackiej przyjmuje formę francuską Maurice, natomiast polski służący Chopina Jan zyskuje imię Januš, co należy chyba potraktować jako próbę dodatkowej polonizacji, gdyż kulturze słowackiej takie imię jest obce, istnieje w niej natomiast imię Ján. Na tym jednak wykaz przykładów jaskrawej egzotyzacji, której można by przypisać intencje socrealistyczne, w powojennym słowackim tłumaczeniu Lata w Nohant się kończy. Imiona większości pozostałych bohaterów $\mathrm{w}$ utworze są zachowane $\mathrm{w}$ wersji identycznej z oryginalną, co nie dziwi, gdyż poza osobami służących wszystkie są postaciami historycznymi. Podobnie wiele realiów czy faktów, które pojawiają się w replikach, to również realia i fakty historyczne, jak na przykład w rozmowie Chopina i Wodzińskiego:

Chopin: [...] Ty dawno byłeś w Warszawie?

Wodziński: Parę lat...

Chopin: Ciekawy jestem, czy się tam bardzo zmieniło? [...] Pamiętasz ten dom, tyle razy koło niego przechodziłem... Wiesz, taki niski, koło samej Wareckiej, z kolumnami... Na pierwszym piętrze kolumienki... Mówiła mi moja Ludwika kochana. To i pani Marynia będzie teraz tam chodziła. Warszawska ulica, fiakry jadą. A Marynia taka... elegancka... i mama $\mathrm{z}$ okna wygląda... ojciec od Loursa wraca... [...] Warszawa wielka, wolne miasto... wielkie sale koncertowe, orkiestry lepsze od paryskiej, parki, piękne ogrody, na Woli, gdzie mnie żegnano, budowle, pałace... Teatr, gdzie śpiewała Konstancja, przemieniony. (s. 73-74)

30 T. Brzostowska-Tereszkiewicz, 2015: Przekład modernistyczny (modele i opozycje)... 
Chopin: [...] Ty si už dávno nebol vo Varšave?

Wodziński: Niekol'ko rokov...

Chopin: Som zvedavý, či sa tam vela zmenilo. [...] Pamätáš si ten dom, tolko raz som prešiel okolo neho... Vieš, taký nízky, popri samej Vareckej, so stĺpmi... Na prvom poschodí stl̂piky... Moja milovaná Ludka mi vravela... Teraz ta bude chodit aj pani Maryna... Varšavská ulica, fiakre letia. A Maryna taká... elegantná... a mama pozerá z obloka... otec sa vracia od Loursa... [...]. (s. 62).

Owo nagromadzenie realiów i faktów historycznych nie pozostawiło tłumaczowi wielkiego pola manewru: jedynym sposobem przybliżenia ich słowackiemu odbiorcy było dokładne, wręcz literalne ich tłumaczenie i opatrzenie przypisami. W zacytowanym fragmencie Jánsky, co prawda, ułatwił sobie zadanie, opuszczając fragment repliki, lecz w całym utworze to jedyne takie miejsce. Nigdzie w przekładzie nie zastosował natomiast żadnego przypisu. Tymczasem bez peritekstów dla słowackiego odbiorcy nieczytelne mogą być zwłaszcza niektóre ukryte znaczenia, jak na przykład aluzja do brzydoty pomnika Chopina w Warszawie w dalszym ciągu dialogu kompozytora z Wodzińskim:

Wodziński: W jakimś kącie ogrodu piękny pomnik Chopina...

Chopin: A toś mnie rozśmieszył... Cha, cha, cha, cha (trochę przez łzy) Wyobrażam sobie, jakie czupiradło postawią... z brązu... Chopin $\mathrm{z}$ brązu... No, nie?... (s. 74$)^{31}$

Wodziński: V nejakom peknom kútiku záhrady pekný pomník Chopina...

Chopin: Ale si ma rozosmial... Cha, cha, cha, cha... (Trochu cez slzy). Viem si predstavit, aké strašidlo tam postavia... z bronzu... Chopin $\mathrm{z}$ bronzu... No nie?... (s. 62)

albo do pośmiertnych losów serca Chopina w replice George Sand:

George Sand: Gdzież ja mogę być twoją przyjaciółką, Chopin, kiedy ja nic o tobie nie wiem. Gdzie ty jesteś w ogóle, Chopin? Gdzie jest twoje serce? (s. 70)

Sandová: Kdeže ja môžem byt' tvojou priatel'kou, Chopin, ked’ o tebe nič neviem. Kde ty vôbec žiješ, Chopin? Kde je tvoje srdce? (s. 60)

$31 \mathrm{Na}$ intertekstualność tego fragmentu utworu zwraca uwagę A. Krajewska, 2004: Komedia polska dwudziestolecia międzywojennego. Tradycjonaliści i nowatorzy. Poznań, Wydawnictwo Naukowe Uniwersytetu im. Adama Mickiewicza, s. 95. 
Nie zawsze czytelna jest też ironia. Z sytuacją taką mamy do czynienia przykładowo w akcie I, w dialogu Wodzińskiego i George Sand na temat Nohant:

Wodziński: [...] Przecież to jest prześliczne! Te cudne drzewa, te róże, ten trawnik...

George Sand (z ożywieniem): Prawda? Prawda? A okolica! Przecież te wąwozy, te rozpadliny, te równiny pól. Czy to panu nie przypomina polskich stepów?

Wodziński: Polskich stepów? Owszem, owszem... tylko że ja jestem z Poznańskiego. Mamy wyższą kulturę rolną... (s. 10)

Wodziński: [...] Ved’ to je prekrásne! Tie užasne stromy, tie rúže, ten trávnik... Sandová (s oživením): Však? Však? A to okolie? Ked’ len človek pozrie na tie úvozy, doliny, tie šíre rovné polia. Nepripomína vám to pol'ské stepi?

Wodziński: Pol'ské stepi? Ba hej, ba hej... lenže... ja som z Poznanska. Mame vyššiu hospodársku kultúru. (s. 13)

lub w akcie III, w wymianie zdań między Chopinem a Sand, kiedy kompozytor informuje pisarkę o swojej decyzji wyjazdu z Nohant:

Chopin: [...] Zabieram Jana ze sobą. Nacierpiał się już dosyć razem ze mną w tym uroczym Nohant.

George Sand: Zawsze cierpicie. Nowa martyrologia polska. (s. 69)

Chopin: [...] Januša beriem so sebou, Natrpel sa už dost', aj spolu so mnou v tom čarovnom Nohante.

Sandová: Vy vždy len trpíte. Nová pol’ská martyrológia. (s. 58)

Nawet jeśli udało się przełożyć zacytowane fragmenty z zachowaniem zawartej w nich ironii, to ze względu na jej osadzenie w kulturze polskiej wątpliwe jest, czy będzie ona czytelna dla słowackiego odbiorcy. Ironia bowiem - podobnie jak aluzja - zakłada, że to, czego dotyczy, musi być rozpoznawane przez odbiorcę, a jej odczytanie uzależnione jest od znajomości przez niego kontekstu ${ }^{32}$. Ograniczone możliwości odczytania ironii sprawiają, że osłabieniu ulega komizm utworu i może dlatego nasi sąsiedzi zza Tatr uznali Lato w Nohant za melodramat ${ }^{33}$,

32 Na temat ironii w przekładzie zob. A. Tomczak, 2017: Ironia modernistyczna $i$ nowy rodzaj biografii. „Białostockie Studia Literaturoznawcze”, nr 10, s. 138, 141.

33 R. Mrlian, red., 1990: Encyklopédia dramatických umení Slovenska 2: M-Ž..., s. 205. 
podczas gdy w Polsce utwór - zgodnie z intencją autora - uznaje się za komedię $^{34}$.

Jeśli mnogość przypisów stanowi cechę przekładu socrealistycznego, to pod tym względem Jánskiego wersja Lata w Nohant nim nie jest. Jednoznaczną kwalifikację modelu przekładu utrudniają również dosyć liczne słowacyzacje. W pół drogi między udomowieniem a wyobcowaniem stoi przekład imienia wielkiej młodzieńczej miłości Chopina - Marii Wodzińskiej: w oryginale Marynia, w przekładzie Maryna, choć pisownia słowacka przewiduje formę Marína. Można to wytłumaczyć chęcią zachowania polskiego kolorytu kulturowego imienia, gdyż użycie formy słowackiej przywodziłoby na myśl niepożądane skojarzenie z jednym z dzieł kanonu słowackiej literatury narodowej - poematem Marína romantycznego poety Andreja Sladkoviča. Nazwisko George Sand podlega dostosowaniu do normy słowackiej i zyskuje formę Sandová. Słowacyzacji podlegają także: poufała wersja nazwiska uczennicy Chopina - Panny de Rosiéres (w oryginale nazywanej Rozjerką, w przekładzie słowackim - Rózką), poufałe wersje imion Chopina (w oryginale Frycek, w przekładzie Frydo), Wodzińskiego (w oryginale Antoś, w przekładzie Antón) oraz siostry kompozytora Ludwiki (w oryginale Ludwika, w przekładzie L’udka). Można to, co prawda, uznać za przejaw dostosowania tekstu do masowego odbiorcy, co stanowiłoby kolejną cechę przekładu socrealistycznego, jednakże w słowackiej wersji utworu naturalizacja dotyczy nie tyko imion postaci. W większości przypadków w replikach formy zwrotu per pan, pani tłumaczone są zgodnie z normą języka słowackiego jako tzw. wykanie, czyli z zastosowaniem zaimka drugiej osoby liczby mnogiej. Zdarzają się w słowackiej wersji repliki, w których postaci, zwracając się do George Sand, używają pochodzącego z języka francuskiego słowa madame:

Wodziński: O! Pani tak wcześnie? (s. 8)

Wodziński: Ó! Madame, tak zavčasu? (s. 12)

Jednak przekładu z użyciem tej formy zwrotu nie można uznać za egzotyzację, jest ona tylko pozorna, gdyż leksem madame (w nowszej wersji madam) jest udomowiony w języku słowackim ${ }^{35}$.

34 Choć po stronie polskiej przyjęło się określenie, jakiego w stosunku do swojego utworu użył w jego podtytule sam Iwaszkiewicz, jednak wśród badaczy i krytyków klasyfikacja genologiczna Lata $w$ Nohant również wzbudza pewne wątpliwości. Na ten temat zob. M. Józefacka, 1970: Komedia poetycka dwudziestolecia międzywojennego. „Pamiętnik Literacki”, nr 3, s. 97-100; A. Krajewska, 2004: Komedia polska dwudziestolecia międzywojennego..., s. 82-83.

35 Slovníkový portál Jazykovedného ústavu L. Štúra SAV, https://slovnik.juls.savba.sk/ [dostęp: 25.11.2020].

\begin{tabular}{l|l|l} 
PLS.2021.11.01.09 & s. $18 \mathrm{z} 24$
\end{tabular} 
Z ewidentną naturalizacją mamy do czynienia w tłumaczeniu sceny, w której pod koniec aktu I Jan informuje panią domu o tym, co będzie na obiad:

Jan [...]: Proszę pani, proszę pani. Bo to jest suflet! (s. 33)

Januš [...]: Prosím, madame, prosím, madame, dnes máme vajcový nakyp. (s. 31)

Słowacyzacji podlega tu nazwa potrawy (vajcový nakyp — „budyń jajeczny”), choć język słowacki zna słowo suflé, a zatem przekład dosłowny byłby możliwy. Podobnie w przypadku pulardy, której sposób podziału przy stole przez George Sand stał się dla Chopina pretekstem do ostatecznego rozstania z kochanką.

George Sand: Wyjazd z tego domu po dziesięciu latach naszej poufałości mógł mieć inny pretekst niż nieszczęsna pularda, którą tak niefortunnie podzieliłam. (s. 66)

Sandová: Odchod $\mathrm{z}$ tohto domu po desiatich rokoch našej intímnej známosti mohol mat inú zámienku než toho neštastného kapúna, ktorého som tak bezmyšlienkovite delila. (s. 56)

W języku słowackim istnieje leksem pulard, choć dla przeciętnego Słowaka zapewne jest bardziej egzotyczny niż kapún: pierwsze ze słów wymienia tylko akademicki słownik wyrazów obcych, podczas gdy drugie znaleźć można w kilku słownikach języka słowackiego ${ }^{36}$.

Wydaje się więc, że autor drugiego słowackiego tłumaczenia Lata $w$ Nohant starał się aktualizować tekst do kultury rodzimej na tyle, na ile tylko było to możliwe, co sprawia, że tłumaczenie to, mimo okoliczności historycznych, w jakich powstało, ostatecznie nie wpisuje się w model przekładu socrealistycznego: ani nie zachowuje konsekwentnie obcości, ani nie poddaje utworu skrajnej domestykacji. A ponieważ Lato w Nohant jest utworem głęboko zanurzonym w kulturę polską, oryginalny koloryt kulturowy okazuje się największą przeszkodą w przeniesieniu dramatu Iwaszkiewicza na grunt słowacki.

Losy drugiego słowackiego tłumaczenia Lata $w$ Nohant potoczyły się nieco tylko lepiej od przekładu przedwojennego. Translacja Jánskiego została zainscenizowana i wystawiona w 1981 roku na scenie Słowackiego Teatru Narodowego w Bratysławie (premiera odbyła się 3 października). Zwraca uwagę rok inscenizacji: był to czas stanu wojennego w Polsce; okres, o którym, oceniając słowacko-polskie relacje w zakresie literatury, Hvišč pisze:

36 Ibidem. 
[...] najhoršie sa javí obdobie po vypuknutí pol’ských udalosti roku 1980. [...] $\mathrm{Na}$ začiatku osemdesiatych rokov tu ešte pôsobila istá zotrvačnost' [...] potom prišiel náhly pokles. [...] Riadiace miesta udržiavali v kultúrnej verejnosti fámu všeobecného úpadku Pol’ska a pol’skej kultúry (ako negatívneho dôsledku politických nepokojov) a hermeticky eliminovali všetko [...], čo by túto fámu mohlo narušit alebo dokonca vyvrátit ${ }^{37}$.

Sztuka Iwaszkiewicza ponownie nie wzbudziła zachwytu wśród krytyków, którzy zwracali uwagę na niewyraźny rys komediowy utworu i raczej skupiali się na inscenizacji niż na dramacie, który był jej podstawą. Nie wiadomo, jak twórcy teatralni zinterpretowali utwór, ale jeden z krytyków określił go jako dramat o George Sand ${ }^{38}$. Inscenizacja utrzymała się w repertuarze teatru do 10 czerwca 1984 roku, odegrano ją 64 razy, bo taką liczbę repryz podaje zapis w archiwum Instytutu Teatralnego w Bratysławie ${ }^{39}$. Czy zdjęto ją z afisza wskutek decyzji politycznych, o jakich pisze Hvišč, czy po prostu dlatego, że nie zainteresowała publiczności - trudno powiedzieć. W każdym razie od tamtego czasu, mimo istnienia dwóch tłumaczeń, sztuka Iwaszkiewicza nie pojawiła się więcej w repertuarze słowackich teatrów. W tym czasie w Polsce utwór był inscenizowany sześciokrotnie, a od jego powstania do dziś - w sumie 50 razy $^{40}$. Przy czym nie jest to jedyny polski utwór sceniczny o Chopinie. Jednak dla Polaków Chopin to kompozytor światowego formatu, a przede wszystkim kompozytor narodowy. Dla Słowaków zaś jest on, co prawda, kompozytorem rangi światowej, ale jednym z wielu, w dodatku na tyle nieistotnym, że jeśli wierzyć serwisowi internetowemu Google Maps, nigdzie na Słowacji nie ma ulicy, placu, skweru czy jakiejś innej lokalizacji nazwanej jego nazwiskiem. Nie znaczy to, że twórczość Chopina jest naszym sąsiadom zza Tatr obca, choć jego muzykę postrzegają przede wszystkim jako źródło smutku albo przynajmniej nieodleg-

37 J. Hvišč, 1997: Nová bilancia: slovensko-pol’ké literárne vztahy po roku 1945.., s. 82.

38 M. Jarábek, 1981: Svieže i nevýrazné tóny komédie. „Smena”, roč. 34, č. 250 (22.10.1981), s. 6. Inne recenzje: G. Mačugová, 1981: Nenápadný vstup do novej sezóny: Leto v Nohante bez sentimentálnej romantiky. „Lud”, roč. 34, č. 243 (14.10.1981), s. 5; F-a, 1981: Bez vrcholných výkonov: Leto v Nohante na Malej scéne SND v Bratislave. „Hlas ludu”, roč. 27, č. 236 (6.10.1981), s. 3.

39 eTHEATRE.SK, Divadelný ústav Bratislava, Inscenácie, https://etheatre.sk/du_vade mecum/perma linkdu?xid=fb3c2a07c729406ebe644651186bda54\&modeView=LIST [dostęp: 17.11.2020].

40 Hasło Lato w Nohant w: Encyklopedia teatru polskiego, http://www.encyklopediateatru. pl/sztuki/1256/lato-w-nohant [dostęp: 7.01.2021]. Szczegółowy przegląd utworów scenicznych - głównie polskich - na temat Chopina przedstawił Andrzej Hejmej w artykule Chopin i jego muzyka w sztukach scenicznych. Dostępne w Internecie: http:// www.chopin.pl/w_scenicznych.pl.html [dostęp: 18.12.2020].

\begin{tabular}{l|l} 
PLS.2021.11.01.09 & s. 20 z 24
\end{tabular} 
łej od niego melancholii ${ }^{41}$. Sama postać kompozytora i jego losy chyba jednak niezbyt ich interesują.

\section{Literatura}

Bednárová K., 2015: Kontexty slovenského umeleckého prekladu 20. storočia. W: O. Kovačičová, M. Kusá, zost.: Slovník slovenských prekladatelov umeleckej literatúry. 20. storočie. A-K. Bratislava, Veda - vydavatel'stvo SAV, s. $15-73$.

Bolecki W., 2002: Modernizm w literaturze polskiej XX wieku. Rekonesans. „Teksty Drugie", nr 4, s. 11-34.

Brzostowska-Tereszkiewicz T., 2015: Przekład modernistyczny (modele i opozycje).W: W. Bolecki, W. Soliński, M. Gorczyński, red.: Współczesne dyskursy konfliktu. Literatura - język - kultura. Warszawa, IBL PAN, s. 45-90. Čavojský L., 1999: Slovenská činohra SND 1932-1938 v zrkadle dramaturgie. W: M. Mistrík a kolektív: Slovenské divadlo v 20. storočí. Bratislava, Veda vydavatel'stvo SAV, s. 82-110.

Encyklopedia teatru polskiego. Dostęne w Internecie: http://www.encyklopedia teatru.pl/sztuki/1256/lato-w-nohant [dostęp: 18.12.2020].

eTHEATRE.SK, Divadelný ústav Bratislava, Inscenácie, https://etheatre.sk/du_ vademecum/ [dostęp: 17.11.2020].

Fox D., 2009: Gra przestrzenia w sztuce Jarosława Iwaszkiewicza „Lato w Nohant" $i$ w jej scenicznych realizacjach. W: V. Sajkiewicz, E. Wąchocka, red.: Przestrzenie we współczesnym teatrze i dramacie. Katowice, Wydawnictwo Uniwersytetu Śląskiego, s. 68-79.

Hejmej A., [online]: Chopin i jego muzyka w sztukach scenicznych. Dostępne w Internecie: http://www.chopin.pl/w_scenicznych.pl.html [dostęp: 18.12.2020].

Hochel B., 1985: Koncepcia prekladu včera, dnes a zajtra. W: J. Vilikovský, red.: Preklad včera a dnes. Bratislava, Slovenský Spisovatel', s. 226-231.

Hvišč J., 1997: Nová bilancia: slovensko-polské literárne vztahy po roku 1945.

W: J. Hvišč, red.: Slovensko-polské jazykové a literárne vzṫahy. Bratislava, T.R.I. Médium, s. $76-88$.

Hvišč J., 2000: Národné povedomie v medziliterárnych súvislostiach. W: J. Hvišč, red.: Historické a kultúrne zdroje slovensko-polských vztahov. Bratislava, Lufema, s. 67-87.

41 Zob. hasło Melancholickost' výrazu w: L. Plesník a kolektív, 2008: Tezaurus estetických výrazových kvalit. Nitra, Univerzita Konštantína Filozofa, Ústav literárnej a umeleckej komunikácie, s. 364. 
Irzykowski K., 1966/1967: J. Iwaszkiewicz - Lato w Nohant. W: Przewodnik teatralny. Jarosław Iwaszkiewicz: Lato w Nohant. Białystok, Państwowy Teatr Dramatyczny im. Al. Węgierki, s. 6. Dostępne w Internecie: e-teatr.pl/ files/programy/51299/lato_w_nohant_teatr_wegierki_bialystok_1967.pdf [dostęp: 20.09.2020].

Iwaszkiewicz J., 1936-1937: Lato w Nohant: akt I: „Skamander. Miesięcznik poetycki”, 1936, rocz. 10 (t. 10), z. 77, s. 516-534; akt II: „Skamander. Miesięcznik poetycki”, 1937, rocz. 11 (t. 11), z. 78-80, s. 26-43; akt III: „Skamander. Miesięcznik poetycki”, 1937, rocz. 11 (t. 11), z. 81-83, s. $104-121$.

Iwaszkiewicz J., 1949: Lato w Nohant. Warszawa, Czytelnik.

Iwaszkiewicz J., 1975: Leto v Nohante. W: J. Sedlák, vyb.: Moderná pol’ská dráma. Bratislava, Tatran, s. 7-73.

Jarábek M., 1981: Svieže i nevýrazné tóny komédie. „Smena”, roč. 34, č. 250 (22.10.1981), s. 6.

Józefacka M., 1970: Komedia poetycka dwudziestolecia międzywojennego. „Pamiętnik Literacki", nr 3, s. 77-111.

Kovačičová O., Kusá M., zost., 2015: Slovník slovenských prekladatelov umeleckej literatúry. 20. storočie. A-K. Bratislava, Veda - vydavatel'stvo SAV.

Kovačičová O., Kusá M., zost., 2017: Slovník slovenských prekladatelov umeleckej literatúry. 20. storočie. $L-\check{Z}$. Bratislava, Veda - vydavatel'stvo SAV.

Krajewska A., 2004: Komedia polska dwudziestolecia międzywojennego. Tradycjonaliści i nowatorzy. Poznań, Wydawnictwo Naukowe Uniwersytetu im. Adama Mickiewicza.

Kročanová D., 2019: Impulzy a inovácie v slovenskej dráme medzi rokmi 1920_ 1948. W: D. Kročanová: Antológia slovenskej drámy 1920-1948. Bratislava, Univerzita Komenského, s. 350-359.

Krzywicka I., 1937: Przegląd teatralny. „Skamander. Miesięcznik poetycki”, rocz. 11 (t. 11), z. $78-80$, s. $61-64$.

Mrlian R., red., 1990: Encyklopédia dramatických umení Slovenska 2: M-Ž. Bratislava, Veda - vydavatel'stvo SAV.

Plesník L. a kolektív, 2008: Tezaurus estetických výrazových kvalít. Nitra, Univerzita Konštantína Filozofa, Ústav literárnej a umeleckej komunikácie.

Ritz G., 1995: Stosunek niejednoznaczny, czyli Jarosław Iwaszkiewicz wobec wła$d z y$. „Teksty Drugie”, nr 1, s. 146-155.

Russocka J., 1972: Literatura słowacka w polskich czasopismach okresu międzywojnia. W: M. Bakoš, red.: Vztahy slovenskej a pol'skej literatúry od klasicizmu po súčasnost'. Bratislava, Veda - Vydavatel'stvo SAV, s. 193-206.

Slovníkový portál Jazykovedného ústavu L. Štúra SAV, https://slovnik.juls.savba.sk [dostęp: 25.11.2020]. 
Štefko V., 2011: Od realizmu $k$ moderne 1890-1938. W: V. Štefko a kolektív: Dejiny slovenskej drámy 20. storočia. Bratislava, Divadelný ústav, s. 15-43. Tomczak A., 2017: Ironia modernistyczna i nowy rodzaj biografii. „Białostockie Studia Literaturoznawcze", nr 10, s. 137-154.

Valcerová A., 2016: Przekład poezji w Słowacji po roku 1945. M. Buczek, tłum. „Przekłady Literatur Słowiańskich”, t. 7, cz. 1, s. 78-96.

Zajac P., 1985: Tvorivost' prekladu. W: J. Vilikovský, red.: Preklad včera a dnes. Bratislava, Slovenský Spisovatel', s. 271-276.

\section{Lucyna Spyrka \\ Okolo slovenských prekladov Leto $v$ Nohante od Jaroslava Iwaszkiewicza}

RESUMÉ | Dráma Jaroslava Iwaszkiewicza Leto $v$ Nohante má črty modernistickej drámy. Dielo bolo preložené do slovenčiny dvakrát: prvýkrát pred vojnou, jeho divadelné naštudovanie si však u slovenského publika nezískalo uznanie a vzhladom na biografiu prekladatela A. Žarnova bol preklad odsúdený na zabudnutie. Dráma sa opät preložila do slovenčiny v 70. rokoch, teda počas obdobia normalizácie vo vtedajšom Česko-Slovensku. Tento historický kontext umožňuje predpokladat', že preklad ma črty socialistického realizmu. Avšak samotný preklad Iwaszkiewiczovej drámy sa proti takémuto zaradeniu bráni. Povojnová slovenská verzia diela vyšla v tlačenej i scénickej podobe, jej divadelná inscenácia sa však opät nestretla s vel'kým záujmom slovenskej strany. Príčiny tejto skutočnosti nemožno hladat v samotnom preklade, ale v odlišnom postavení Chopinovej hudby v polskej a slovenskej kultúre.

KLÚČOVÉ SLOVÁ | polská literatúra v slovenskom preklade, preklad drámy, dejiny prekladu, kontexty prekladu, Jarosław Iwaszkiewicz

\section{Lucyna Spyrka}

\section{Wokół słowackich przekładów Lata w Nohant Jarosława Iwaszkiewicza}

STRESZCZENIE | Dramat Jarosława Iwaszkiewicza Lato $w$ Nohant ma cechy dramatu modernistycznego. Utwór był tłumaczony na język słowacki dwukrotnie: po raz pierwszy przed wojną, jednak jego inscenizacja nie zyskała uznania słowackiej publiczności, a ze względu na biografię tłumacza - A. Žarnova - przekład w latach powojennych został skazany na zapomnienie. Nowe słowackie tłumaczenie powstało w latach 70., czyli w okresie „normalizacji”, jaka obowiązywała w ówczesnej Czechosłowacji po zdławieniu Praskiej Wiosny. Ów kontekst historyczny nasuwa przypuszczenie, że nowa translacja może mieć charakter przekładu socrealistycznego, lecz przy dokładniejszej analizie broni się ona przed taką jednoznaczną klasyfikacją. Powojenna słowacka wersja utworu była publikowana drukiem oraz $\mathrm{w}$ formie inscenizacji, jednak wersja teatralna nie spotkała się 
z większym zainteresowaniem publiczności, czego przyczyny tkwią nie w samym przekładzie, lecz w odmiennej pozycji Chopina i jego muzyki w kulturze polskiej i słowackiej.

SŁOWA KLUCZOWE | literatura polska w przekładzie słowackim, przekład dramatu, historia przekładu, konteksty przekładu, Jarosław Iwaszkiewicz

LUCYNA SPYRKA | dr hab., adiunkt w Instytucie Literaturoznawstwa Uniwersytetu Śląskiego w Katowicach, badaczka literatur i kultur zachodniosłowiańskich, przede wszystkim słowackiej. Jej zainteresowania naukowe koncentrują się na zagadnieniach polsko-słowackich kontaktów kulturalnych, komparatystyki literackiej i kulturowej, estetyki dramatu i teatru oraz na problemach z zakresu teorii, historii i praktyki przekładu. Autorka monografii, m.in.: Radošinské naivné divadlo - między konwencja a kontestacja (2004) oraz Dramat słowacki $w$ Polsce. Przekład $w$ dialogu kultur bliskich (2016). Autorka tłumaczeń tekstów naukowych i artystycznych z języka słowackiego i czeskiego, m.in. J.Ch. Korec: Po barbarzyńskiej nocy (1994). 